\title{
MAKNA PENAMPILAN GENDER PADA ATLET PEREMPUAN CABANG OLAHRAGA TAKRAW: STUDI KASUS PADA SEBUAH SEKOLAH OLAHRAGA DI INDONESIA
}

\author{
Tri Rahayu Mayasari \\ Universitas Nasional Jakarta Selatan \\ 08213443503 \\ trirahayumayasari88@gmail.com
}

Received August 27, 2019, Revised September 22, 2019, Approved November 23, 2019

\begin{abstract}
ABSTRAK
Penelitian ini merupakan bentuk kajian yang dilakukan di sebuah sekolah khusus di Indonesia, yaitu Sekolah Olahraga. Tujuan dari penelitian ini adalah untuk mengamati penampilan gender yang muncul pada atlet perempuan khususnya pada cabang olahraga takraw. Peneliti ingin membuktikan bahwa gender tidak terikat pada jenis kelamin, begitu pula sebaliknya. Metode yang digunakan dalam penelitian ini adalah observasi partisipatif dimana peneliti terlibat langsung dalam aktifitas atlet perempuan, tidak hanya pada cabang olahraga takraw tetapi juga dari cabang olahraga lain. Melalui dua teori tersebut, penelitian yang dilakukan telah membuktikan bahwa atlet perempuan (takraw) tidak menampilkan gendernya sesuai dengan konstruksi budaya yang melekat pada perempuan pada umumnya.
\end{abstract}

Kata kunci: sekolah olahraga, atlet perempuan, takraw, penampilan gender, fesyen

\begin{abstract}
This study is sort of observation done at a particular school in Indonesia namely sport school. The purpose of this study is to observe the gender performance of female athletes especially in Takraw as one of competition sport. Observer expects to prove that gender is not bond to sex, and vise versa. The method used in this study is participative observation where the observer gets involved in female athletes' activities, not only in Takraw but in another sport branch also. Through the theories, the research has proven that female athletes do not show their gender as the cultural construction on common women.
\end{abstract}

Key words: sport school, female athlete, takraw, gender performance, fashion

\section{PENDAHULUAN}

\section{Latar Belakang}

Penelitian ini merupakan bentuk kajian yang dilakukan di sebuah sekolah khusus di Indonesia, yaitu Sekolah Olahraga. Peneliti ingin membuktikan bahwa gender tidak terikat pada jenis kelamin, begitu pula sebaliknya. Teori yang digunakan sebagai rujukan penelitian serta penulisan tesis ini mengacu pada teori gender (Judith Butler, 1999) yang menjelaskan tentang bagaimana gender bisa bersifat fleksibel, bergantung pada kondisi, tempat dan waktu. Dengan mengacu pada teori ini, peneliti mencoba mengungkap penampilan gender pada atlet perempuan terpaku pada jenis kelamin atau tidak. Penampilan fisik atau gaya pakaian (fesyen) merupakan 
Jurnal Pujangga Volume 5, Nomor 2, Desember 2019

ISSN P 2443-1478

ISSN E 2443-148

salah satu objek penting dalam pengamatan sehingga merupakan sebuah keharusan untuk menyertakan teori fesyen (Fraid, 1992) untuk memahami makna fesyen yang melekat pada gaya pakaian yang dikenakan oleh atlet perempuan (takraw). Melalui dua teori tersebut, penelitian yang dilakukan telah membuktikan bahwa atlet perempuan (takraw) tidak menampilkan gendernya sesuai dengan konstruksi budaya yang melekat pada perempuan pada umumnya. Atlet perempuan (takraw) bisa tampil sangat maskulin meskipun mereka berjenis kelamin perempuan. Selain itu, gaya rambut dan pakaian atlet perempuan (takraw) tidak hanya menyampaikan pesan atas sebuah identitas diri, tetapi juga kelompok yaitu cabang olahraga takraw.

Maskulinitas serta feminitas merupakan dua hal yang seringkali nampak pada penampilan seseorang. Entah disengaja atau tidak, hal tersebut dirasa telah menjadi sebuah pilihan bagi seseorang dalam menentukan karakter penampilan yang diinginkan dan tentunya disesuaikan dengan identitas diri yang ingin ditunjukkan kepada khalayak ramai. Beragam fenomena muncul dalam kehidupan sosial terkait dengan cara berpenampilan, sebagian besar perempuan memilih tampil feminim melalui beberapa simbol seperti rambut panjang, rok pendek, aksesoris dan make up. Simbol-simbol ini cenderung merujuk pada fashion. Secara etimologi, fashion berasal dari bahasa Latin factio, yang berarti membuat atau melakukan. Definisi sederhana dari fashion merujuk pada sesuatu yang dilakukan seseorang, bukan tentang apa yang dikenakan seseorang (Malcolm,1996:12). Walaupun pada kenyataanya, masyarakat bisa mengetahui peran serta status sosial berdasar pada apa yang dikenakan, yang biasanya berhubungan dengan pakaian. Fashion bisa diwujudkan melalui beberapa media, salah satunya adalah pakaian. Pakaian tidak hanya dianggap sebagai media penutup tubuh, tapi juga merupakan media yang menghubungkan antara diri dan dunia sosial dimana hal tersebut juga mampu memberi bentuk dan warna pada pembedaan dan ketimpangan sosial. Selain itu, melalui pakaian, manusia bisa mendapatkan sumber kesenangan atas keindahan serta berkesempatan untuk merefleksikan diri (Twigg, 2007:288). Meskipun demikian, tingkah laku/ perilaku ketika berinteraksi dengan lawan bicara (publik) juga merupakan salah satu hal yang bisa dijadikan indikator feminitas seseorang. Misalnya, berbicara dengan suara halus, duduk dengan cara yang sangat sopan, berjalan dengan berlenggak lenggok seperti model yang sedang berjalan di atas panggung.

Penelitian tentang atlet perempuan pernah dilakukan oleh Center of Feminist Research, University of Southern California. Dalam penelitian yang berjudul Gender in Televised Sports, permasalahan tentang ketimpangan gender terhadap atlet perempuan diutarakan. Sekitar 20 tahun lalu, para komentator olahraga di negara-negara Barat seringkali memberikan komentar negatif 
Jurnal Pujangga Volume 5, Nomor 2, Desember 2019

ISSN P 2443-1478

ISSN E 2443-148

terhadap atlet perempuan karena peran mereka yang tidak seimbang dengan atlet laki-laki. Atlet perempuan dianggap tidak bisa berkarir dalam berbagai cabang olahraga seperti halnya atlet lakilaki. Media televisi memberikan andil besar dalam pembentukan gender stereotype terhadap atlet perempuan sehingga memberikan pengaruh terhadap eksistensi atlet tersebut. Penelitian lainnya juga pernah dilakukan oleh Dorie dari Universitas Illinois, Urbana. Ia mengangkat judul From Masculine Myths To Girl Power Realities: The Athletic Female Body And the Legend Of Title IX. Penelitian ini mengulas tentang pandangan negatif terhadap perempuan yang bertubuh atletis. Sekitar 40 tahun lalu, perempuan yang bertubuh atletis dinilai sebagai seseorang yang berperilaku menyimpang. Hal ini dikarenakan masyarakat pada saat itu masih percaya dengan beberapa mitos tentang pengaruh bahaya fisik dan psikologi atas partisipasi perempuan dalam bidang olahraga. Seiring dengan perkembangan ilmu pengetahuan yang juga diiringi oleh pergerakan kaum feminis pada tahun 1980an, pandangan negatif terhadap perempuan bertubuh atletis bergeser. Tubuh atletis pada perempuan tidak lagi dianggap sebagai suatu hal yang aneh tetapi malah dianggap sebagai bagian dari modernitas dan kecantikan. Hal ini didukung dengan menjamurnya pusat-pusat kebugaran perempuan, seperti fitness center dan sebagainya. Kondisi ini membuktikan bahwa pergeseran cara pandangan telah mempengaruhi konstruksi budaya saat itu. Penelitian ini mencoba mengungkap tentang proses perubahan cara pandang terhadap mitos perempuan bertubuh atletis. (Geissler, Dorie A. 2012)

\section{Rumusan Masalah}

Adapun beberapa permasalahan yang ingin dibahas dalam penelitian ini adalah sebagai berikut.

1. Bagaimana atlet perempuan (takraw) menampilkan gender?

2. Bagaimana atlet perempuan (takraw) memahami penampilan gender tersebut?

\section{Tujuan Penelitian}

Penelitian ini dilakukan untuk memenuhi beberapa tujuan, antara lain sebagai berikut.

1. Ingin mengetahui cara yang digunakan atlet perempuan (takraw) dalam menampilkan ekspresi gendernya.

2. Ingin menjelaskan pemahaman yang ditangkap oleh atlet perempuan (takraw) atas penampilan gender yang dimunculkan. 
Jurnal Pujangga Volume 5, Nomor 2, Desember 2019

ISSN P 2443-1478

ISSN E 2443-148

\section{Tinjauan Pustaka}

Melalui teori gender, peneliti menekankan bahwa jenis kelamin (sex) dan gender adalah dua hal yang berbeda. Jika perbedaan ini tidak dipahami dengan benar maka akan menimbulkan kesalahpahaman dalam menjalankan peran dalam masyarakat. Selain itu, pemahaman ini merupakan hal yang sangat penting mengingat penelitian penampilan gender yang dilakukan oleh peneliti berkaitan erat dengan jenis kelamin dan gender atlet perempuan. Dengan demikian, peneliti bisa mengamati perilaku atlet perempuan berdasar jenis kelamin atau gender. Pada obyek penelitian, pemahaman tentang jenis kelamin dan gender perlu digunakan untuk memahami bahwa atlet yang berjenis kelamin perempuan tidak berperilaku sesuai dengan “gender stereotype" konservatif. (Lips, 2008: 5)

Teori gender memberikan toleransi terhadap perempuan untuk tampil di luar konstruksi budaya, sehingga adakalanya perempuan bisa tampil feminin dan maskulin pada kesempatan yang berbeda. Inilah yang disebut dengan "gender performative", penampilan yang tidak hanya mengacu pada satu gender saja. Misalnya, atlet perempuan senantiasa tampil maskulin saat berlatih fisik di lapangan, namun ketika melakukan ibadah sholat mereka pasti mengenakan mukena, bukan baju koko dan sarung. Dengan menggunakan teori gender, peneliti ingin memberikan pemahaman tentang "gender stereotype" yang selama ini dimaknai dengan pola pikir yang kurang tepat dalam kehidupan bermasyarakat. Dalam berbagai budaya, laki-laki dianggap sebagai mereka yang mempunyai kekuatan sosial lebih daripada perempuan sehingga laki-laki dinilai lebih mendominasi ranah publik, dan perempuan hanya menjadi bagian subordinasi. Faktanya, saat ini telah banyak perempuan hebat yang menduduki jabatan strategis bahkan menjadi pimpinan di ranah publik, seperti Sri Mulyani (mantan Menteri Keuangan era Susilo Bambang Yudiono), Puan Maharani (Ketua DPP PDIP), Rieke Diah Pitaloka (aktivis dan anggota DPR RI) dan masih banyak lainnya. Fakta ini membuktikan bahwa "gender stereotype" tentang perempuan yang hanya didasarkan pada konstruksi konservatif (tradisional) tidak bisa dipaksakan diterima pada semua kalangan. Gender (peran) yang dipertukarkan pada laki-laki dan perempuan dalam kehidupan masa kini pada akhirnya akan mengubah stereotype konservatif. Kondisi ini menunjukkan bahwa stereotype mempunyai komponen yang dinamis, salah satu aspek dari komponen tersebut merupakan persepsi dan proses bagaimana karakter-karakter berubah. (Lips, 2008:4)

Pakaian merupakan material yang tidak bisa dipisahkan dari fesyen. Melalui pakaian, identitas diri bisa disampaikan, baik identitas personal atau kelompok. Selain merepresentasikan kelas sosial, pakaian juga bisa merepresentasikan identitas gender. Jenis dan model pakaian yang 
Jurnal Pujangga Volume 5, Nomor 2, Desember 2019

ISSN P 2443-1478

ISSN E 2443-148

dikenakan bisa mewakili peran gender yang ingin dimainkan dalam kehidupan. Stereotype bagi perempuan yang mengenakan celana adalah ia tertarik dengan maskulinitas yang biasanya identik dengan aktifitas sportif dan energik. Beberapa pandangan konservatif menganggap bahwa aktifitas sportif dan energik hanya layak berada dalam dunia laki-laki sehingga apabila ada perempuan yang mengenakan celana maka ia dianggap "tomboi". Seiring berkembanganya jaman, pemakaian celana pada perempuan telah mendapatkan toleransi masyarakat mengingat semakin banyaknya perempuan di ranah publik yang membutuhkan tampilan sportif dan energik guna menunjang profesi. (Davis, 1992: 39)

\section{METODE PENELITIAN}

Penelitian ini menggunakan metode kualitatif untuk menyajikan secara langsung hakikat hubungan antara peneliti dan responden. melakukan penelitian secara keseluruhan. Metode ini dinilai mempunyai kepekaan serta adaptasi terhadap penajaman pola-pola nilai yang dihadapi (Moleong, 1989:5). Penelitian ini dilakukan pada sebuah sekolah olahraga yang dilengkapi

dengan sistem asrama bagi seluruh muridnya, baik laki-laki ataupun perempuan. Mereka wajib tinggal di asrama selama hari aktif sekolah, dan diperbolehkan pulang ketika hari libur saja. Data yang diperoleh dari penelitian ini merupakan kombinasi data yang di dapatkan pada rentan waktu berbeda. Pada tahun 2012 peneliti pernah bekerja di sekolah ini sebagai Ibu Asrama Putri, selang beberapa bulan peneliti mengundurkan diri karena suatu hal. Kemudian, pada awal tahun 2014 peneliti melanjutkan pengamatan tersebut dengan obyek yang sama, yaitu atlet perempuan cabang olahraga takraw. Pendekatan kualitatif sangat sesuai diterapkan dalam penelitian ini mengingat fokus penelitian ini berhubungan dengan tingkah laku manusia. Melalui metode ini, peneliti bisa mendeskripsikan latar dan interaksi yang kompleks dari partisipan. (Suyanto,2005:174)

\section{HASIL DAN PEMBAHASAN}

Atlet perempuan sangat menghargai tubuhnya. Tanpa disadari prinsip yang tadinya lahir karena tuntutan serta kebutuhan dari dunia olahraga, akhirnya melebur menjadi suatu identitas diri. Bagi para atlet perempuan, tubuh telah menjadi media untuk menunjukkan sebuah identitas diri. Dari sini bisa diketahui bahwa ternyata tubuh Setiap cabang olahraga mempunyai konstruksi tubuh masing-masing, misalnya atlet perempuan dari cabang olahraga voli pantai mayoritas 
Jurnal Pujangga Volume 5, Nomor 2, Desember 2019

ISSN P 2443-1478

ISSN E 2443-148

bertubuh tinggi, sedangkan cabang olahraga judo dan gulat sangat identik dengan tubuh kekar dan berotot. Dengan gambaran seperti ini, tubuh bisa dianalogikan seperti spon yang mampu menyerap makna-makna tertentu, selain juga bermakna politis (Synnott, Anthony: 2002).

Bagian-bagian tubuh telah terbagi sedemikian rupa ke dalam ranah personal dan publik. Bagian-bagian tubuh yang tampak oleh indera penglihat merupakan bagian yang terfungsikan secara publik, artinya bagian tubuh tersebut bisa menimbulkan respon baik secara positif maupun negatif dari masyarakat, sekalipun orang lain yang tidak mengenal diri kita sama sekali. Bagian depan tubuh biasanya menjadi penanda jenis kelamin, sedangkan bagian belakang tubuh kurang begitu diperhitungkan. Bagian wajah dan dada menjadi penanda untuk mengetahui apakah jenis kelamin seseorang itu perempuan ataukah laki-laki. Meskipun demikian, saat ini banyak orang melakukan pengelabuan identitas seks dengan melakukan operasi pada organ genital, seperti Dorce Gamalam yang melakukan operasi alat kelamin. Dengan contoh tersebut kita tidak bisa selalu berpegang teguh bahwa bentuk fisik bagian depan merupakan identitas seks seseorang yang sesungguhnya. Pada kehidupan bermasyarakat, kondisi seperti itu bisa menimbulkan gender troble mengingat adanya perubahan fisik secara drastis. Perubahan fisik secara drastis ini menyebabkan bias gender dimana adanya tumpang tindih antara bentuk tubuh dan peranan si pemilik tubuh berdasarkan gender. Misalnya, laki-laki yang tadinya memiliki penis, lalu melakukan operasi dengan menyembunyikan penisnya, akan mendapatkan peran gender yang rancu di masyarakat.

Fungsi tubuh secara sosial menggambarkan bagaimana sebuah tubuh mendapatkan respon dari lingkungan sosial. Respon tersebut bisa berasal dari hasil interaksi pemilik tubuh terhadap orang-orang yang ada di sekitarnya. Seorang atlet gulat akan berlatih keras untuk membentuk ototnya sehingga otot tersebut bisa memberikan kekuatan saat bertanding di arena. Selain itu, ia juga harus menjaga berat badan agar bisa melakukan gerakan-gerakan tertentu, dan tentunya tidak menyulitkan lawan tanding saat membanting tubuhnya ke lantai. Dalam konteks penelitian ini, fungsi tubuh secara sosial bisa terlihat pada bagaimana sebuah jenis cabang olahraga mempunyai kecenderungan untuk memiliki tubuh para atletnya, artinya setiap atlet dari jenis olahraga manapun seolah mempunyai keterikatan untuk menampilkan identitas cabang olahraga sesuai karakter cabang olahraga tersebut. Saat peneliti melakukan pengamatan pada pola pergaulan atlet perempuan, khususnya cabang olahraga takraw, terlihat bagaimana mereka bergaul dengan orang-orang atau kelompok yang memberikan penerimaan positif atau terbuka terhadap diri mereka, artinya atlet takraw tidak akan bergaul dengan mereka yang tidak bisa atau bahkan tidak mau menghargai keberadaan atlet takraw dengan segala kekurangan dan 
Jurnal Pujangga Volume 5, Nomor 2, Desember 2019

ISSN P 2443-1478

ISSN E 2443-148

kelebihannya. Pada penjelasan sebelumnya, sempat dijelaskan sekilas bagaimana karakterisasi serta penampilan atlet takraw, sikap yang cenderung arogan dan maskulin terkadang bukanlah hal yang bisa diterima bagi atlet lainnya. Karena merasa memiliki bentuk tubuh maskulin, mereka biasanya bersikap layaknya laki-laki, tegas dan sedikit kasar, dan hal ini merupakan efek dari fungsi tubuh secara sosial dimana tubuh telah memberikan pengaruh pada pola relasi sosial.

Penampilan gender yang ditampilkan oleh atlet perempuan (takraw) bisa diamati melalui beberapa perilaku, misalnya cara berjalan, cara berbicara, cara berinteraksi dengan sesama/ lawan jenis. Cabang olahraga takraw merupakan jenis olahraga yang membutuhkan keahlian gerakan tubuh lentur dan lincah. Para pemain takraw dituntut agresif, cekatan dan lentur saat memainkan bola takrow baik saat mengoper ke teman satu tim ataupun ke arah lawan. Beberapa gerakan dalam olahraga ini mungkin terlihat agak ekstrim bagi perempuan, misalnya pemain harus menendang bola takraw dengan kaki, dada atau kepala. Tidak jarang tubuh pemain terbentur lantai dengan keras karena harus mengarahkan bola ke arah lawan. Karena gerakan yang begitu aktif saat melakukan latihan fisik, hal ini berimbas pada perilaku atlet perempuan (takraw) di luar waktu latihan, saat mereka melakukan aktifitas pribadi, misalnya saat berada di dalam kamar asrama, atau saat berkumpul di ruang TV asrama. Kebiasaan melakukan gerakan atletik, seperti menendang atau gerakan maskulin lainnya, membuat para atlet perempuan (takraw) terbiasa melakukan hal tersebut pada aktifitas di ruang publik dimana aktifitas tersebut tidak berhubungan dengan kegiatan latihan cabang olahraganya. Peneliti sempat mengamati bagaimana beberapa atlet perempuan (takraw) tidak sungkan mengangkat kakinya setinggi mungkin pada sandaran papan kasur di kamar asrama. Selain itu, beberapa dari mereka juga tidak canggung menekan tombol channel pada TV asrama menggunakan jempol kaki dari tempat duduk dikarenakan rusaknya remote.

\section{PENUTUP}

\section{Simpulan}

Penelitian ini mengamati tentang penampilan gender pada atlet perempuan (takraw) pada salah satu sekolah olahraga di Indonesia. Penelitian ini mengungkap tentang cara atlet perempuan (takraw) menampilkan gendernya. Dari penelitian kualitatif diketahui bahwa atlet perempuan (takraw) menampilkan gender melalui perilaku dan bentuk tubuh. Beberapa perilaku yang diamati berfokus pada beberapa hal, misalnya penampilan fisik (tata rias, gaya rambut dan pakaian), memainkan peran gender dan cara memahami seksualitas. Dengan mempunyai penampilan fisik maskulin, atlet perempuan bisa menunjukkan identitas gendernya. Identitas 
ISSN P 2443-1478

ISSN E 2443-148

gender tersebut mencerminkan kecenderungan peran gender yang ingin dimainkan dalam kehidupan sehari-hari. Selain itu, bentuk tubuh maskulin (berotot) dianggap sebagai representasi diri secara personal dan kelompok. Maskulinitas tersebut membuktikan bahwa mereka yang berjenis kelamin perempuan bisa tampil seperti halnya laki-laki, artinya atlet perempuan (takraw) tidak memaknai gender berdasar jenis kelamin. Perilaku dan penampilan maskulin yang ditampilkan oleh atlet perempuan (takraw) membuktikan bahwa gender tidak selalu mengikuti

konstruksi budaya (konservatif). Meskipun berjenis kelamin perempuan, mereka bisa melakukan hal-hal yang juga dilakukan oleh laki-laki di lingkungan olahraga ini. Budaya olahraga di sekolah ini memberikan toleransi serta penerimaan terhadap penampilan maskulin oleh atlet perempuan (takraw) karena tampilan tersebut sesuai secara konteks. Karena berprofesi sebagai atlet maka merupakan hal yang sangat wajar apabila mereka berpenampilan maskulin.

Peran gender yang dimainkan oleh perempuan tidak bisa didasarkan oleh jenis kelamin saja. Konstruksi yang melekat pada peran seorang perempuan sangat bergantung pada tempat, waktu dan ruang sehingga hal tersebut bersifat fleksibel. Peran gender yang dimainkan oleh atlet perempuan (takraw) dalam lingkungan olahraga membuktikan bahwa gender tidak terbatas pada jenis kelamin. Budaya olahraga mempunyai konstruksi berbeda terhadap perempuan, budaya ini memberikan toleransi bahkan mendukung perempuan untuk tampil maskulin, bukan untuk merusak konstruksi budaya tradisional yang telah ada, tetapi lebih pada menyesuaikan dengan konteks yang ada.

\section{Saran}

Adapun mengenai saran penelitian berikutnya diharapkan penelitian ini dapat ditinjau dari analisis semiotik/ simbolik yang membedah tentang makna gaya penampilan (gaya rambut, aksesoris, pilihan warna/ jenis pakaian) yang nantinya akan bermanfaat untuk pembahasan mendalam mengenai kajian semiotik. 


\section{DAFTAR PUSTAKA}

Butler, Judith. 1999. Gender Trouble: Feminism and the Subversion of Identity. New York \& London: Routledge.

Davis, Fred. 1992. Fashion, Culture and Identity. Chicago; London: The University of Chicago Press

Suyanto, Bagong dan Sutinah. Metode Penelitian Sosial. Jakarta: Kencana Prenada Media Group

Synnott, Anthony. 2002. Tubuh Sosial: Simbolisme Diri dan Masyarakat. Diterjemahkan oleh Pipit Maizer. Yogyakarta: Jalasutra

Twigg, Julia. 2007. Clothing, Age and the Body: Critical Review. United Kingdom: Cambridge University Press

Geissler Dorie A. 2012. From Masculine Myth To Girl Power Realities: The Athletic Female Body And The Legend of The Title IX. 